ABDI: Jurnal Pengabdian dan Pemberdayaan Masyarakat ISSN: 2656-369X (Print), 2684-8570 (Online)

Volume 1 No. 2, Desember 2019

http://abdi.ppj.unp.ac.id/index.php/abdi

Email: abdi@ppj.unp.ac.id

DOI: https://doi.org/10.24036/abdi.vli2.17

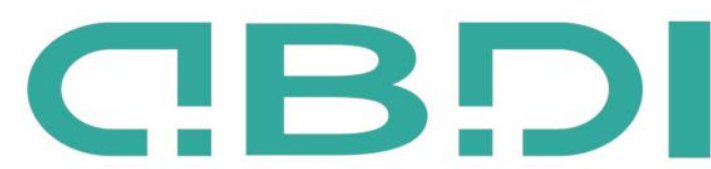

ABDI: JURNAL PENGABDIAN DAN PEMBERDAYAAN MASYARAKAT

\title{
Penulisan Notasi Angka Menggunakan Parnumation 3.0 Sebagai Upaya Pemanfaatan Teknologi Pada Era Disrupsi
}

\author{
Fajry Sub'haan Syah Sinaga $^{1}$, Emah Winangsit ${ }^{2}$ \\ ${ }^{1,2}$ Jurusan Sendratasik Universitas Negeri Padang
}

Email: fajry.sinaga@fbs.unp.ac.id; emah_winangsit@fbs.unp.ac.id

\begin{abstract}
Abstrak
Berdasarkan penelitian (S. S. Sinaga, 2010) seorang guru musik harus mampu menuliskan notasi musik dalam proses pembelajaran musik. Artikel ini memberikan pengantar tentang cara menulis notasi musik bernomor menggunakan Parnumation 3.0 sebagai upaya untuk memanfaatkan teknologi di era digital. Penelitian ini menggunakan analitik deskriptif dengan metode pengumpulan data yang terdiri dari observasi dan studi literasi yang mendukung langkah-langkah untuk mengirimkan notasi angka menggunakan parnumation 3.0. Penelitian membuktikan bahwa penggunaan parnumation 3.0 memberikan kemudahan dalam penulisan notasi angka.
\end{abstract}

Kata kunci: Notasi angka, Parnumation 3.0, Penggunaan.

\section{Abstract}

Based on research (S. S. Sinaga, 2010) a music teacher must be able to transcribe a music notation in the music learning process. This article provides an introduction on how to write numbered music notation using Parnumation 3.0 as an effort to utilize technology in the digital age. This study uses descriptive analytics with data collection methods consisting of observation and literacy studies that support the steps for submitting number notations using parnumation 3.0. The research proves that the use of parnumation 3.0 provides a compromise on notation.

Keyword: Numbered notation, Parnumation 3.0, Using

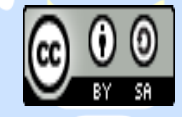

Received: 26 November 2019

Revised: 4 Desember 2019

Available Online: 6 Desember 2019

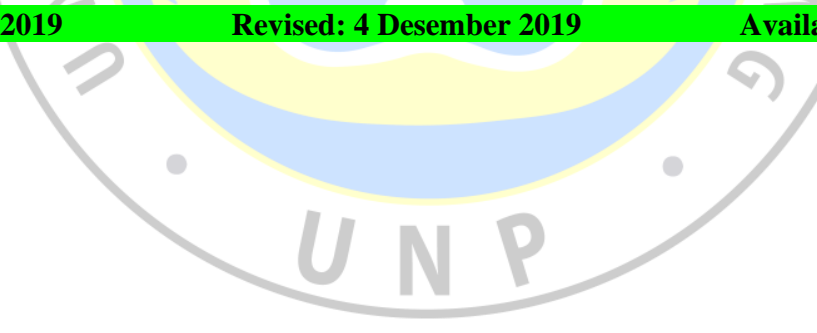




\section{Pendahuluan}

Membaca notasi musik bagi sebagian orang adalah hal yang sangat rumit, telebih dalam kegiatan pembelajaran musik. Berdasarkan wawancara dengan Risnawati selaku ketua MGMP Seni Budaya Kabupaten Solok, hampir 40\% guru Seni Budaya dan Keterampilan di Kabupaten Solok bukan lulusan dari Pendidikan Musik, melainkan dari Pendidikan Rupa maupun Pendidikan Tari. Dalam pembelajaran bernyanyi maupun paduan suara, banyak guru yang mengalami kesulitan dalam membaca notasi musik. Menurut (Herdinasari et al., 2013), membaca notasi musik menjadi lebih mudah dan menyenangkan jika menggunakan beberapa media atau software. Hal tersebut juga sesuai dengan pendapat dari (S. S. Sinaga, 2010) yang mengatakan bahwa seorang guru musik harus dapat mentranskripsikan sebuah not sehingga dapat dipelajari oleh siswa dalam proses pembelajaran musik.

Penggunaan media menjadi alternatif yang sangat membantu dalam proses pembelajaran musik (F. S. S. Sinaga, Maestro, Winangsit, \& Yensharti, 2019, p. 143). Kemampuan membaca notasi musik harus dimiliki seseorang jika ingin mengikuti sebuah paduan suara, hal tersebut sesuai dengan pernyataan (Inten, Permatasari, \& Mulyani, 2016) tentang kemampuan awal yang harus dimiliki seseorang ketika bernyanyi paduan suara adalah membaca notasi. (Tobing, 2018, p. 63) mengatakan bahwa manajemen materi lagu menjadi salah satu penentu keberhasilan pembelajaran paduan suara. Peneliti menyadari pentingnya membaca notasi musik tidak dapat dipisahkan dari kegiatan menulis notasi musik. Parnumation adalah font plugin yang dapat digunakan untuk menuliskan notasi angka menggunakan software penulisan digital (Ramadhani \& Raharjo, 2017, p. 68). Parnumation atau pargodungan adalah font yang dibuat dengan menggunakan aplikasi yang bernama High-Logic FontCreator.

Guru mata pelajaran Seni Budaya dan Keterampilan seharusnya memiliki kompetensi seperti membaca dan menulis musik yang dihadirkan melalui pembelajaran praktik secara langsung. Pendidikan musik merupakan sebuah proses untuk memanusiakan manusia selain fungsinya untuk meningkatkan kompetensi dalam bidang musik (Julia, 2017, p. v). Penelitian tentang penulisan notasi angka sudah banyak sekali dilakukan salah satunya oleh (Chrisantyo, Hartanto, \& Nugroho, 2012) yang mengembangkan perangkat lunak untuk mengkonversi notasi balok ke notasi angka, dan (Setyawan, 2018) yang melakukan penelitian tentang sibelius sebagai media dalam meningkatkan kemampuan membaca notasi musik. Sedangkan penulisan tentang parnumation sudah dilakukan oleh (Ramadhani \& Raharjo, 2017), namun hanya membahas masalah teknis terkait dengan penggunaan parumation secara ringkas.

Penulis menyadari bahwa tulisan tentang cara penulisan notasi angka menggunakan perangkat lunak parnumation 3.0 masih jarang sekali, sehingga penulis merasa penting untuk menelaah lebih lanjut tentang penggunaan parnumation 3.0 dalam penulisan notasi angka khususnya bagi guru Seni Budaya pada tingkat SMA di Kabupaten Solok.

\section{Metode Pelaksanaan}

Pengabdian dalam ruang pendidikan merupakan suatu kegiatan yang diarahkan kepada pengembangan pengetahuan ilmiah tentang kejadian-kejadian yang menarik perhatian pendidikan (Manab, 2015). Tujuannya untuk menemukan prinsip-prinsip umum, yaitu penafsiran tingkah laku yang dapat dipakai untuk menerangkan, meramalkan, dan mengendalikan kejadian-kejadian dalam lingkungan pendidikan.

Pengabdian ini menggunakan pendekatan deskriptif analitif yang berarti interprestasi terhadap isi dibuat dan disusun secara sistematik/menyeluruh dan sistematis. Data yang diperoleh berupa kata, gambar, atau perilaku tidak dituangkan dalam bilangan atau angka statistik, melainkan tetap dalam bentuk kualitatif yang memiliki arti lebih kaya dari sekadar angka atau frekuensi (Margono, 2005, p. 39). Pengabdian ini dilakukan di Kabupaten Solok, tepatnya di SMA 2 Gn. Talang - Komplek BPTP Sumbar, Jalan Raya Solok - Padang KM 40, Sukarami - Gn. Talang Kab. Solok. Penentuan lokasi ini dilakukan karena hampir 40\% guru mata pelajaran Seni Budaya dan Keterampilan di Kab. Solok bukan merupakan lulusan dari Pendidikan Musik. Hal tersebut terkait dengan kompetensi yang harus dimiliki oleh pengajar seni salah satunya adalah menuliskan notasi musik baik berupa balok maupun angka. 
Informan yang dituju dalam penelitian ini adalah guru-guru yang tergabung dalam MGMP Seni Budaya dan Keterampilan. Tim peneliti akan melakukan wawancara dengan beberapa dosen musik dan guru mengenai kendala dalam proses pembelajaran notasi musik menggunakan notasi angka dan notasi balok.

Metode pengumpulan data yang digunakan dalam proses pengabdian ni bermacam-macam bentuknya, mulai dari observasi, pengumpulan data, pengambilan dokumentasi terkait dengan lagu dan pelaksanaan pembelajaran di kelas sebagai sumber data yang dapat dikumpulkan. Observasi dilakukan dengan mengamati proses pembelajaran menulis notasi menggunakan notasi angka dan proses penulisan notasi angka menggunakan parnumation 3.0 sebagai salah satu kompetensi yang harus dimiliki oleh guru seni. Studi pustaka digunakan untuk mencari informasi tentang penggunaan notasi angka dalam pembelajaran musik menggunakan perangkat lunak di era digital saat ini. Studi pustaka dapat dilakukan melalui media cetak maupun media internet.

\section{Hasil dan Pembahasan}

\section{Nilai Not dalam Penulisan Notasi Angka}

Dalam penulisan notasi angka, simbol dasar yang digunakan berupa angka yaitu 1 (do) 2 (re) 3 (mi) 4 (fa) 5 (sol) 6 (la) 7(si). Angka tersebut dapat digunakan pada berbagai tanda mula dan tanda kunci. Pada umumnya, pada awal teks lagu sudah dituliskan nada dasar apa yang digunakan, sehingga mahasiswa hanya menyanyikan berdasarkan simbol angka yang dituliskan. Sebagai contoh pada lagu Ibu Kita Kartini cipt. W.R. Supratman yang akan dijelaskan pada gambar berikut:

\section{Ibu Kita Kartini}

Do $=E$

W.R. Supratman

4/4 Andante Maestoso

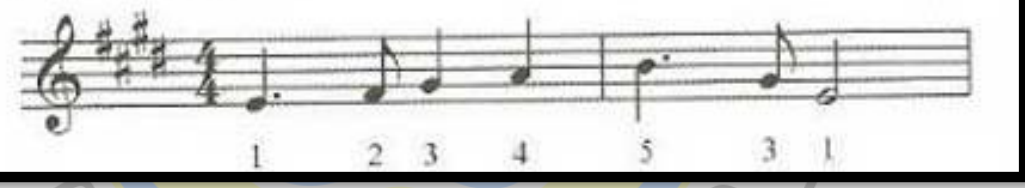

Gambar 1. Penulisan Lagu Ibu Kita Kartini dalam Notasi Balok dan Angka

Penulisan notasi angka pada partiture diatas masih sedikit membingungkan jika tidak ditulis menggunakan simbol nilainya yang diwujudkan dalam notasi balok. Parnumation 3.0 memberikan kemudahan dan memperjelas penulisan notasi angka sehingga dapat dinyanyikan sesuai dengan nilai notasi yang berlaku. Perhatikan gambar berikut:

\section{Ibu Kita Kartini}

Do $=E$ 4/4

Andante Maestoso

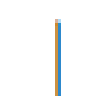

$1 \overline{2} \quad 3 \quad 4$
Composer: W.R Supratman

Transcribed: Emah Winangsit

Gambar 2. Penulisan Notasi Angka Menggunakan Parnumation 3.0 
Meskipun notasi musik ditulis menggunakan notasi angka, tetapi sudah sangat jelas perbedaan panjang - pendeknya nilai not tersebut. Dalam penulisan notasi angka terdapat simbol yang berfungsi untuk membedakan nilai ketukan suatu not, yaitu dengan wujud garis yang berada di atas not tersebut. Silakan perhatikan not dibawah ini,

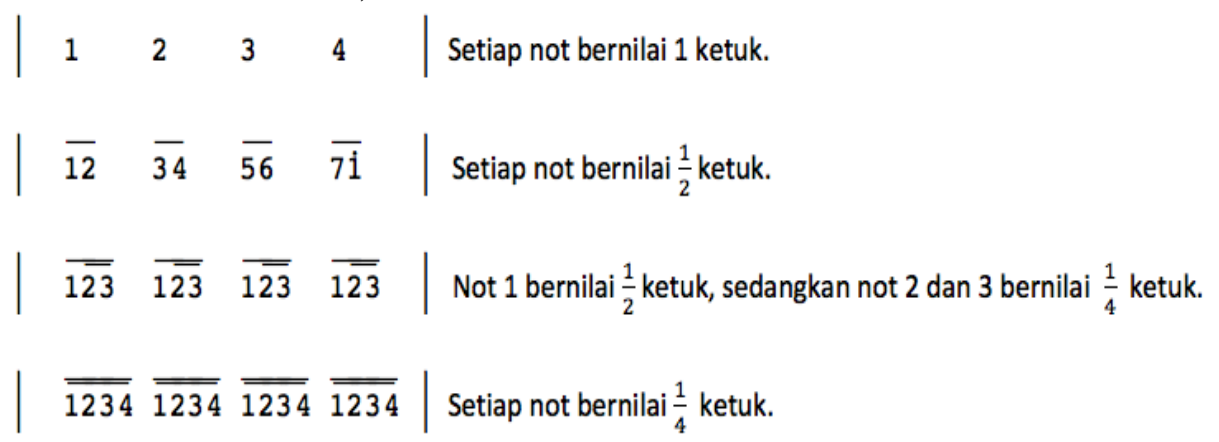

Langkah yang dapat digunakan untuk menambahkan nilai ketukan pada notasi angka menggunakan Parnumation 3.0 adalah dengan menambahkan tanda titik (.) setelah nada yang ingin diperpanjang. Penggunaan tanda titik (.) bernilai 1 ketukan dan akan berubah sesuai dengan tanda beam atau garis yang berada di atasnya. Jika dilihat pada Fig. 3. Setelah nada 1 pada birama kedua terdapat tanda titik (.), itu berarti nada 1 dibunyikan lebih panjang sebanyak 2 ketukan.

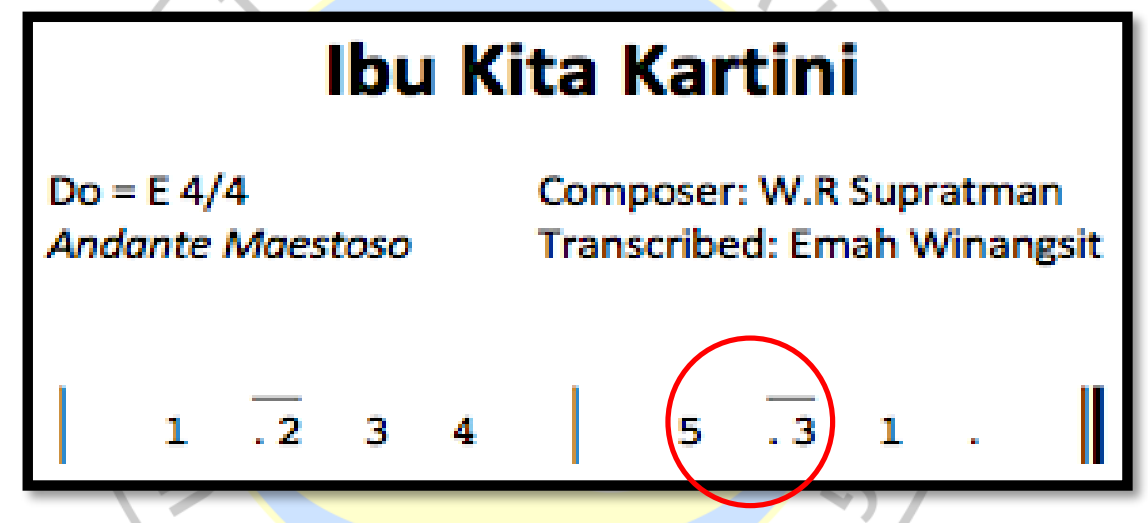

\section{Gambar 3. Tanda titik (.) berfungsi untuk menambahkan ketukan pada nada yang terletak di depannya.}

Dalam kasus lain, tanda titik (.) dapat menambah nilai ketukan pada nada yang ada didepannya sebanyak setengah ketuk atau seperempat ketuk tergantung tanda garis yang berada di atas titik (.) tersebut. Penulisan not tersebut pada Parnumation 3.0 dilakukan dengan menekan huruf (j) atau (k) atau (1) sebelum titik (.) maupun not yang ingin ditulis. Untuk membantu memahaminya, silakan perhatikan gambar berikut.

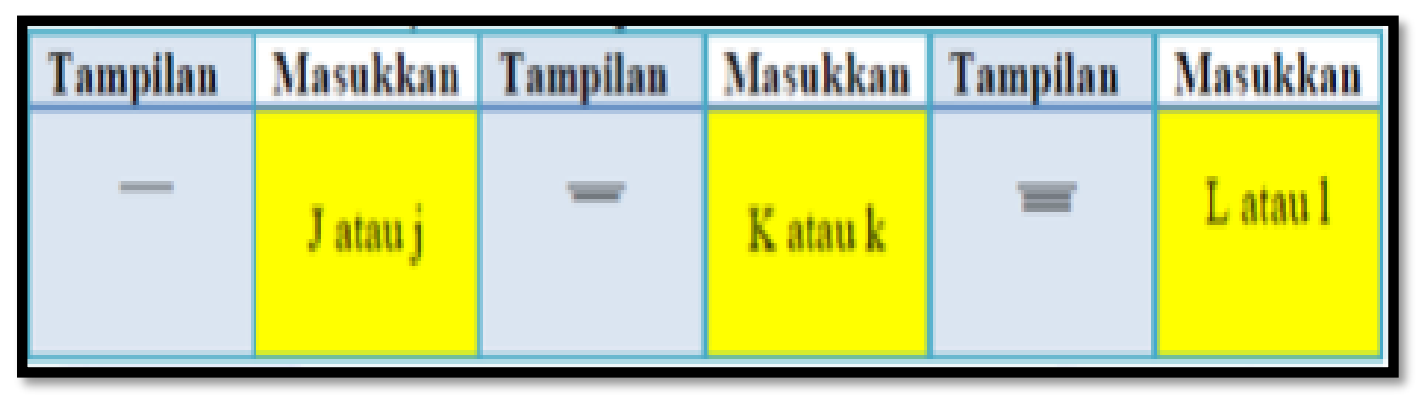




\begin{tabular}{|c|c|c|c|c|c|c|}
\hline Tampilan & Masukkan & Tampilan & Masukkan & Tampilan & Masukkan & lanjut \\
\hline$\overline{2}$ & j. 2 & $\overline{3 .}$ & j 3 . & $\overline{04}$ & j0 04 & dst. \\
\hline $2 \overline{03}$ & $\mathrm{j} 2 \mathrm{k} 03$ & $4 . \overline{5}$ & j 4 k. 5 & 23. & j 2 k 3. & dst. \\
\hline$\overline{4 \overline{05 \overline{23}}}$ & $\mathrm{j} 4 \mathrm{k} 0 \mathrm{k} 5 \mathrm{~L} 23$ & $\overline{2 \overline{\overline{34}}}$ & k 2 L 34 & $\overline{\overline{3232}}$ & $\mathrm{~L} 3 \mathrm{k} 2 \mathrm{j} 32$ & dst. \\
\hline
\end{tabular}

Gambar 4. Cara Memasukan Not Sepersekian Menggunakan Parnumation 3.0

\section{Penulisan Oktaf dalam Notasi Angka}

Langkah yang digunakan untuk menuliskan notasi angka dari 1 - 7 menggunakan Parnumation 3.0 dapat dilakukan dengan cara biasa yaitu mengetik angka 1 (do) , 2 (re) , 3 (mi) , 4 (fa), 5 (sol), 6 (la), dan 7 (si) tetapi untuk menuliskan not pada oktaf yang lebih tinggi atau rendah membutuhkan cara yang berbeda, silakan perhatikan pada gambar berikut ini:

\begin{tabular}{|c|c|c|c|c|c|c|}
\hline Output & Input & Output & Input & Output & Input & cont \\
\hline \multirow{3}{*}{ i } & {$[$ Shift $]+[1]$} & \multirow{3}{*}{$\dot{2}$} & {$[\mathrm{Shift}]+[2]$} & \multirow{3}{*}{$\dot{3}$} & {$[$ Shift $]+[3]$} & \multirow{3}{*}{$\begin{array}{l}\text { still the same } \\
\text { until ? }\end{array}$} \\
\hline & or & & or & & Or & \\
\hline & {$[\mathrm{a}]+[1]$} & & {$[\mathrm{a}]+[2]$} & & {$[\mathrm{a}]+[3]$} & \\
\hline \multirow{3}{*}{1} & [q] & \multirow{3}{*}{2} & {$[\mathrm{w}]$} & \multirow{3}{*}{3} & [e] & \multirow{3}{*}{$\begin{array}{l}\text { still the same } \\
\text { until ? }\end{array}$} \\
\hline & or & & or & & or & \\
\hline & {$[\mathrm{s}]+[1]$} & & {$[\mathrm{s}]+[2]$} & & {$[s]+[3]$} & \\
\hline$\dot{1}$ & {$[9]+[1]$} & $\dot{2}$ & {$[9]+[2]$} & $\dot{3}$ & {$[9]+[3]$} & $\begin{array}{l}\text { still the same } \\
\text { until } 7\end{array}$ \\
\hline$\frac{1}{\vdots}$ & {$[8]+[1]$} & 2 & {$[8]+[2]$} & 3 & {$[8]+[3]$} & $\begin{array}{l}\text { still the same } \\
\text { until } 7\end{array}$ \\
\hline
\end{tabular}

Gambar 5. Penulisan Notasi Angka pada Oktaf yang Lebih Tinggi atau Rendah

Tanda yang digunakan dalam penulisan oktaf yang berbeda adalah tanda titik (.) yang terletak pada bagian atas atau bawah notasi angka. Jika titik berada pada bagian atas notasi memberikan tanda bahwa nada tersebut pada oktaf yang lebih tinggi, jika tanda titik berada pada bagian bawah memberikan tanda bahwa nada tersebut pada oktaf yang lebih rendah. Silakan perhatikan susunan not dibawah ini,

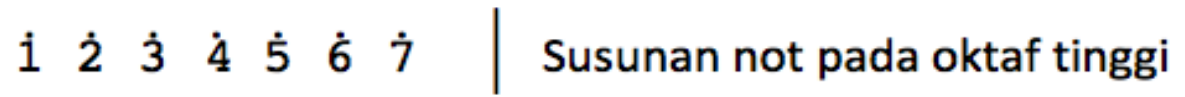

\begin{tabular}{lllllll|l|l}
1 & 2 & 3 & 4 & 5 & 6 & 7 & Susunan not pada oktaf normal
\end{tabular}

\begin{tabular}{lllllll|l}
1 & 2 & 3 & 4 & 5 & 6 & 7 & Susunan not pada oktaf rendah
\end{tabular}

Penulisan Tanda Kromatis dalam Notasi Angka 
Selain tanda titik (.) terdapat tanda garis miring ke atas (/) dan garis miring ke bawah (\). Garis miring ke atas (/) berfungsi untuk menaikan setengah nada dan tanda garis miring ke bawah ( $($ ) berfungsi untuk menurunkan setengah nada. Untuk menuliskannya menggunakan parnumation 3.0, dapat dilihat pada gambar berikut: *tanda dalam kurung tidak perlu dituliskan kembali.

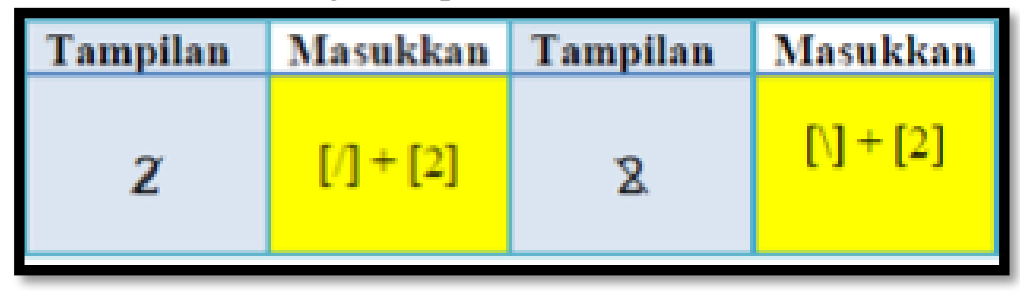

\section{Gambar 6. Cara menuliskan notasi dengansetengah nada lebih tinggi/rendah}

a. Garis miring keatas (/) pada notasi angka sama halnya dengan simbol sharp (\#) dalam simbol musik yang berfungsi menaikan setengah nada, namun dalam penulisan notasi angka, tanda garis tersebut mengenai nada yang ingin dinaikan maupun diturunkan, perhatikan notasi dibawah ini:

$$
\begin{aligned}
& \begin{array}{llllllllllll}
1 & X & 2 & Z & 3 & 4 & A & 5 & B & 6 & B & 7
\end{array} \\
& \text { do di re ri mi fa fi sol sil la li si } \\
& \begin{array}{llllllllllll}
1 & 1^{4} & 2 & 2^{4} & 3 & 4 & 4^{4} & 5 & 5^{4} & 6 & 6^{41} & 7
\end{array} \\
& c \text { cis } d \text { dis e } f \text { fis } g \text { gis a aís } b
\end{aligned}
$$

b. Garis miring kebawah (\) pada notasi angka sama halnya dengan simbol flat (b) dalam simbol musik yang berfungsi menurunkan setengah nada. Penulisan tanda garis tersebut mengenai nada yang dimaksud, perhatikan notasi dibawah ini:

$$
\begin{aligned}
& \begin{array}{llllllll}
1 & 2 & 3 & 4 & 5 & 6 & 7 & \mathbb{R}
\end{array} \\
& \text { do re mi fa sol la si sa } \\
& \begin{array}{lllllllllllll}
1^{b} & 1 & 2^{b} & 2 & 3^{b} & 3 & 4 & 5^{b} & 5 & 6^{b} & 6 & 7^{b} & 7 \\
\text { ces } c & \text { des } & d & \text { es } & \text { e } & f & \text { ges } & g & \text { as } & a & \text { bes } & b
\end{array}
\end{aligned}
$$

\section{Penulisan Garis Birama Menggunakan Parnumation 3.0}

Secara etimologi, birama adalah bagian atau segmen dari suatu garis melodi yang tersusun dalam ruang yang berada diantara dua garis yang tegak lurus $(\mid)$. Ruang Birama atau Bar menunjukan berapa jumlah ketukan yang terdapat dalam ruang tersebut (Saker, 2008).

Dalam istilah musik, birama lebih tepat disebut dengan Time Signature atau tanda waktu yang menunjukan seberapa banyak beat atau ketukan dan berapa nilai setiap ketukan yang ada dalam satu ruang birama. Contoh Time Signature yang umum digunakan yaitu , , , . Sebagai contoh, Time Signature memiliki arti bahwa, dalam setiap ruang birama terdapat 4 ketukan, dan masing-masing ketukan bernilai quarter not atau not seperempatan. Silakan perhatikan notasi berikut, 


\begin{tabular}{|c|c|c|c|c|c|c|c|c|}
\hline Time Signature & 1 & 2 & 3 & 4 & 1 & 2 & 3 & 4 \\
\hline Time Signature & 1 & 2 & 3 & & 1 & 2 & 3 & \\
\hline Time Signature & 1 & 2 & & & 1 & 2 & & \\
\hline
\end{tabular}

Gambar 7. Contoh penulisan susunan not dalam berbagai Time Signature

Penulisan garis birama dalam penulisan notasi angka menggunakan parnumation 3.0 berbeda-beda cara dan jenisnya. Perhatikan gambar berikut supaya lebih jelas dipahami,

\begin{tabular}{|c|c|c|l|c|c|}
\hline Tampilan & Masukkan & Tampilan & Masukkan & Tampilan & Masukkan \\
\hline | & | & $\|$ & (underscore) & $\|$ & + \\
\hline$\|:$ & {[} & $: \|$ & ] & & \\
\cline { 1 - 4 } & & & &
\end{tabular}

Gambar 8. Cara penulisan garis birama pada Parnumation 3.0

\section{Penulisan Legato Menggunakan Parnumation 3.0}

Secara etimologi, legato merupakan istilah musik dari bahasa italia yang berarti diikat. Menurut $\mathrm{KBBI}$, istilah legato berarti menyanyikan atau membunyikan gabungan beberapa not yang berurutan dalam satu waktu secara halus atau tidak terputus-putus. Penulisan legato menggunakan parnumation 3.0 merupakan bagian yang sedikit rumit, namun tetap bisa dipelajari. Silakan perhatikan gambar dibawah ini,

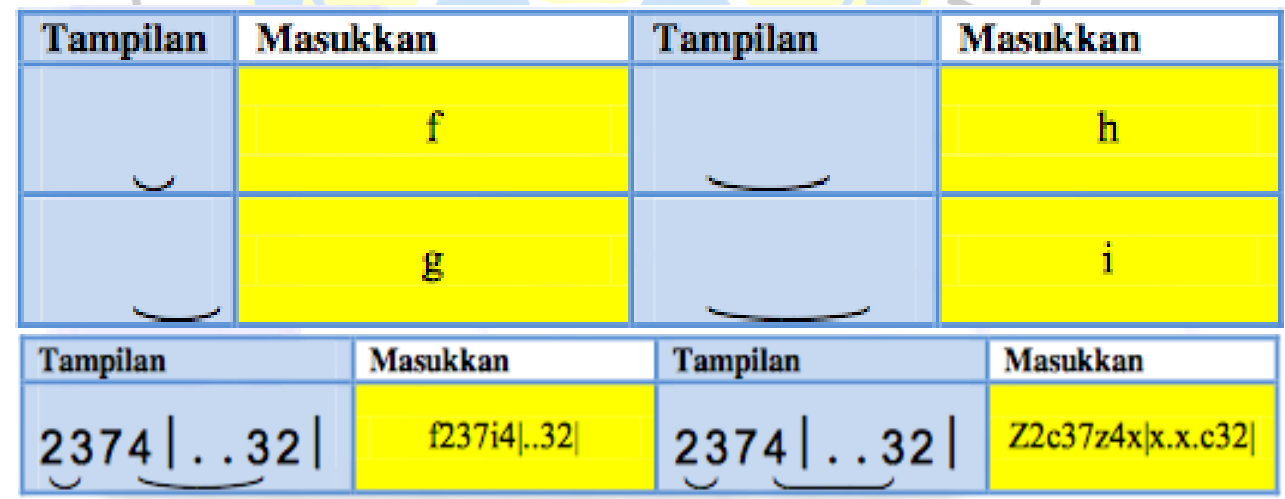

Gambar 9. Cara penulisan legato menggunakan parnumation 3.0

\section{Kesimpulan}

Berdasarkan pembahasan diatas, diharapkan parnumation 3.0 dapat menjadi media penulisan notasi angka sebagai upaya penggunaan teknologi dalam proses pembelajaran musik. Permasalahan dalam membaca notasi musik dapat teratasi dengan penggunaan notasi angka, selain itu kompetensi yang harus dimiliki sebagai calon pendidik musik yaitu dapat mentranskripsi notasi untuk kepentingan pembelajaran musik. Setelah langkah diatas diterapkan pada guru-guru seni Budaya dan Keterampilan, menyatakan bahwa sangat terbantu dengan adanya parnumation 3.0 khususnya dalam penulisan notasi angka sebagai upaya pemanfaatan teknologi di era digital.L 


\section{Daftar Pustaka}

Chrisantyo, L., Hartanto, R., \& Nugroho, L. E. (2012). Pengembangan Aplikasi Konversi Representasi Not Balok Ke Not Angka Untuk Paduan Suara Campur. Jurnal Informatika, 8(1).

Inten, D. N., Permatasari, A. N., \& Mulyani, D. (2016). Literasi Dini Melalui Teknik Bernyanyi. $A L$ MURABBI: Jurnal Studi Kependidikan Dan Keislaman, 3(1), 70-91.

Julia, J. (2017). Pendidikan Musik: Permasalahan dan Pembelajarannya. UPI Sumedang Press.

Manab, H. A. (2015). Penelitian Pendidikan Pendekatan Kualitatif. Kalimedia.

Margono, S. (2005). Metodologi penelitian pendidikan. Jakarta: Rineka Cipta.

Ramadhani, R. A., \& Raharjo, I. B. (2017). Transformation Of Technology On Learning Notation Numbers Through Parnumation 3.0 Media. In Proceeding of International Conference on Art, Language, and Culture (pp. 68-74).

Saker, B. B. M. (2008). Music in Theory and Practice Vol 1. (Marley Magaziner, Ed.). William Glass. Setyawan, D. (2018). Pemanfaatan Software Sibelius sebagai Media Pembelajaran Musik. IMEDTECH: Instructional Media, Design and Technology, 1(2).

Sinaga, F. S. S., Maestro, E., Winangsit, E., \& Yensharti, Y. (2019). Learning and Singing: Thematic Children Songs in Kindergarten. In Seventh International Conference on Languages and Arts (ICLA 2018). Padang: Atlantis Press. Retrieved from https://www.atlantispress.com/article/55914484

Sinaga, S. S. (2010). Pemanfaatan Dan Pengembangan Lagu Anak-Anak Dalam Pembelajaran Tematik Pada Pendidikan Anak Usia Dini/ Tk. Harmonia: Journal of Arts Research and Education. https://doi.org/10.15294/harmonia.v10i1.55

Tobing, O. (2018). Manajemen Paduan Suara Consolatio Universitas Sumatera Utara. Gondang: Jurnal Seni Dan Budaya, 2(2), 57-61. 